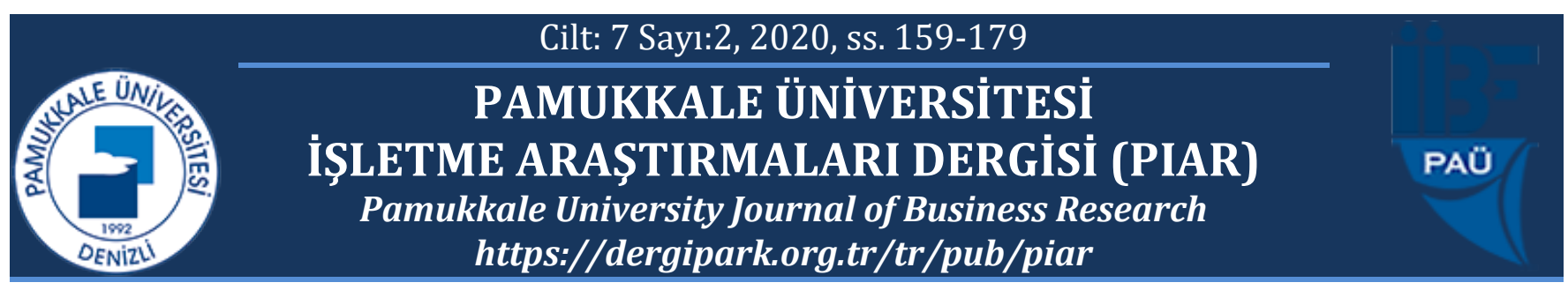

\title{
BOBİ FRS Stoklar Standardının TMS 2 ve VUK Stoklar Maddelerine Göre Karşılaştırılması
}

\section{A Comparison of BOBI FRS Inventories Standard with TMS 2 and VUK Inventories' Articles}

Muhammet Kürşat DAYIOĞLU1*

\section{Günay Deniz DURSUN ${ }^{2}$}

\begin{abstract}
Iİstanbul Aydın Üniversitesi, Lisansüstü Eğitim Enstitüsü, Muhasebe ve Denetimi Bölümü, muhammetdayioglu@stu.aydin.edu.tr, https://orcid.org/0000-0003-4626-9606

2̇̇stanbul Aydın Üniversitesi, Uygulamalı Bilimler Yüksekokulu, gunaydenizdursun@aydin.edu.tr, https://orcid.org/0000-0002-1079-2879

* Yazışılan Yazar/Corresponding author
\end{abstract}

\section{Öz}

Bu çalışmanın amacı, 29.07.2017 tarihinde 30138 sayıl Resmî Gazete'de yayımlanarak 01.01.2018 tarihinden itibaren ticari hayatımiza dahil olan Büyük ve Orta Ölçekli İşletmeler İçin Finansal Raporlama Standardı (BOBI FRS) 6. Bölümünde yer alan stoklar ile ilgili standardın Türkiye Muhasebe Standartları (TMS) 2 Stoklar standardı ve Vergi Usul Kanunu (VUK)'da yer alan stoklarla ilişkili maddelere göre karşılaştırarak standartlar arasındaki farklılıkları ve benzerlikleri ortaya koymaktır. Çalışmada ele alınan stoklar ile ilgili standartlarm birbirleriyle farklılı ve benzerlikleri ilk önce içerik analizi yolu ile incelenmiştir. Yapılan bu inceleme sonucunda standartlar arasinda finansman unsurlarl, maliyet hesaplama yöntemleri ve hizmet sunan işletmelerdeki stok satışının gelir olarak yansitılması işlemlerinde farklılıkların bulunduğu, ilk satın alma, maliyet ölçüm teknik ve hesaplama yöntemleri ile birlikte stoklarm gider olarak kayıtlara alınması işlemlerinin benzerlik taşıdığ $ı$ sonucuna ulaşılmıştır. Ayrıca inceleme sonucunda finansman unsurlarında ortaya çıkan farklılı̆̆ın işletmelerin gelir tablosuna nasıl etkide bulunacağ aktarılmıştır.

Anahtar kelimeler: Stoklar, Muhasebe Standartları, Vergi Usul Kanunu

JEL kodlart: M40, M41, M48

\begin{abstract}
The aim of this study is, to compare with related Turkish Accounting Standards 2 (TMS 2) Inventories and Tax Procedure Law (VUK) inventory articles that is inside Financial Reporting Standard for Large and Medium Sized Enterprises (FRS for LMES/ BOBI FRS) 6th chapter which involved our business life as of 01.01.2018 by publishing on 30138 numbered Official Journal on date 29.07.2017, in addition to prove differences and same case betweeen them. In this work inventory related standarts and differences as well as smilarities between them which has been issued was examined firstly using through content analysis. As a result of this examination, it has been concluded that there are differences among the standards in the financial factors, cost calculation methods and the reflection of the inventory sales in the service providing companies as income. Initial purchasing, cost measurement techniques and calculation methods, and recording of inventories as expenses are similar in terms of standards. Also, it was explained practically how the difference in financing factors will affect the income statement of the enterprises as a result of the examination.
\end{abstract}

Keywords: Inventories, Accounting Standards, Tax Procedure Law

JEL codes: M40, M41, M48 


\section{GİRIŞ̧}

Muhasebe bilimi, ekonomik ve ticari olayların gelişmesi sonucunda günlük ticari hayat içerisinde insanların gereksinim duydukları hesaplaşma işlemlerini karşılamak üzere kendiliğinden ortaya çıkmıştır. M.Ö 4000'li yıllarda ortaya çıktığ her dönemde gelişme göstererek bugün uygulamakta olduğumuz modern muhasebe sistemine yıllar içerisinde evirilmiştir (Aslan, vd., 2016: 151). Muhasebe mevzuatları öncelikle ülkelerin yerel kanunları ile düzenlenirken ülkemizde de 1961 tarihli VUK'a göre düzenlenmektedir (Altıntaş, 2011; İnan, 2010).

Küresel ticari faaliyetlerin artması ile birlikte uluslararası işletmelerin kullanabileceği ortak bir muhasebe dili önemli bir ihtiyaç olarak ortaya çıkmış ve bu konu ile ilgili çeşitli kuruluşlar tarafından çalışmalar yapılmıştır. Bu çalışmalar günümüzde International Accounting Standards Board (IASB)'nin önderliğinde International Financial Reporting Standards Foundation (IFRS Foundation) tarafından sürdürülmektedir. IFRS Foundation standartlar yayımlanmakla birlikte standartların gelişmesi ve uygulanabilirliği üzerine uluslararası alanda çalışmalarına devam etmektedir (Yalkın vd., 2006: 293). Bu çalışmada ele alınan TMS 2 Stoklar standardı Kamu Gözetimi, Muhasebe ve Denetim Standartları Kurumu (KGK) tarafından düzenlenmiş olup IFRS Foundation'ın yayımlamış olduğu IAS 2 Inventories'in Türkçe çevirisi niteliğindedir.

Uluslararası Muhasebe Standartları (UMS)'nin yürürlüğe konulması ile birlikte standartları uygulayabilecek ölçekte olmayan işletmeler için çeşitli uygulama problemleri meydana gelmiş ve standartların uygulanması ancak kamuoyunu bilgilendirme yükümlülügü bulunan şirketler için zorunlu tutulmuştur (Gökçen vd., 2018: 438). Yeterli ölçek büyüklüğüne sahip olmayan işletmelerin muhasebesel işlemlerinin belirli bir standarda oturtulabilmesi için çalışmalar yapılmış ve Avrupa Komisyonu tarafından “2013/34/EUŞirketler için Finansal Raporlama Yükümlülükleri" adı altında tüm şirketler için uygulanması gereken finansal raporlama standartları yönergesi 26 Haziran 2013 tarihinde yayımlanmıştır (Demir ve Bahadır, 2014: 14). Bu gelişmeler 1şığında ülkeler tarafından UMS'leri uygulayamayacak nitelikteki işletmeler için standart oluşturma çalışmalarına başlanmıştır. Ülkemizde muhasebe standartlarını yayımlamak ve uygulamaktan sorumlu kurum olan KGK'nın çalışmaları sonucunda 01.01.2018 tarihinden itibaren başlanmak üzere BOBI FRS 29.07.2017 tarihinde 30138 sayılı Resmî Gazete'de yayımlanarak yürürlüğe girmiştir (Sağlar ve Ever, 2019: 302). İşletmelerin stokları ile ilgili standartlar BOBİ FRS'nin 6.Bölümünde yer almaktadır.

Ülkemizde faaliyetlerini sürdüren işletmelerin hangi standartlara tabi oldukları KGK tarafından düzenlenmiştir. 29100 sayılı Resmî Gazete'de TMS'leri uygulamakla yükümlü olan işletmeler sayılmış, Kamu Yararını İlgilendiren Kuruluşlar (KAYİK) olarak nitelendirebileceğimiz borsada işlem gören işletmeler, finansal yatırım kuruluşları, sigorta ve bankaların TMS'ye göre raporlama yapmaları gerektiği ve kararın ekli listesinde yer almayan işletmelerin isteğe bağlı olarak TMS'yi uygulayabilecekleri belirtilmiştir. TMS'yi uygulamakla yükümlü olmayan işletmeler 2012/4213 sayılı Bakanlar Kurulu Kararına göre bağımsız denetime tabi durumda bulunuyorlar ise KGK'nın 30138 sayılı Resmî Gazete'de yayımlamış olduğu tebliğe göre BOBİ FRS'yi uygulamalıdırlar. BOBİ FRS'ye tabi olan firmalara seçimlik bir hak verilmiş olup diledikleri takdirde BOBİ FRS yerine TMS'yi de 
uygulayabilmektedirler. TMS'yi tercih eden işletmeler iki yıl boyunca tabi oldukları standartları değiştirememektedir. Bağımsız denetime dahil olma kriterleri; işletmelerin aktif toplamı, yıllık net satış hasılatı ve çalışan sayılarıdır. Bu kriterlerdeki hadler düzenli olarak Bakanlar Kurulu tarafından belirlenirken sayılan bu üç kriterin ikisini, birbirini takip eden hesap dönemlerinde sağlayan işletmeler finansal tablolarını bağımsız denetimden geçirmek zorundadır. Bu şartları sağlamayan işletmeler ise yerel vergi mevzuatımız olan VUK'a göre raporlama işlemlerini gerçekleştireceklerdir (Kaya, 2018: 265).

BOBİ FRS'nin, TMS uygulamaları ölçeklerine göre maliyetli ve karmaşık olan işletmelerin kolay bir şekilde UMS'lere yakın raporlama yapabilmelerini sağlamak, VUK'un vergi amaçlı raporlamasının eksik taraflarını kapatıcı ve işletme faaliyetlerine göre daha gerçekçi dönem sonu finansal tabloları ortaya koymak amacı ile oluşturulduğu söylenebilir (Özbirecikli ve Kıymetli Şen, 2018: 484).

Bu çalışmanın amacını, BOBİ FRS 6. Bölümde yer alan stoklar standardını TMS 2 Stoklar standardı ve VUK'da yer alan stoklarla ilişkili maddelere göre karşılaştırarak standartlar arasındaki farklılıkları ve benzerlikleri ortaya çıkarmak oluşturmaktadır. Ayrıca çalışmanın stok standartları hakkında bilgiye sahip olmak isteyen işletme paydaşları ve muhasebe uygulayıcıları açısından faydalı olması amaçlanmıştır. Bu amaca yönelik olarak kaleme alınan çalışmanın 2.bölümünde BOBİ FRS 6.Bölüm Stoklar, TMS 2 Stoklar ve VUK'da yer alan stoklar ile ilişkili maddeler nitel araştırma tekniklerinden içerik analizi yolu ile incelenmiştir. Yapılan bu inceleme sonucunda standartlardaki uygulama farklılıklarına göre ortaya çıkan finansman unsurları, maliyet hesaplama yöntemleri ve hizmet sunan işletmelerdeki stok satışının gelir olarak yansıtılması işlemlerinde farklılıkların bulunduğu sonucuna ulaşılmıştır. Stokların ilk satın alma, maliyet ölçüm teknik ve hesaplama yöntemleri ile birlikte stokların gider olarak kayıtlara alınması işlemlerinin ise BOBİ FRS 6.Bölüm Stoklar, TMS 2 Stoklar ve VUK'da yer alan stoklar ile ilişkili maddeler açısından benzerlik taşıdığı anlaşılmıştır. Çalışmanın 3.bölümünü oluşturan uygulama kısmında ise finansman unsurlarında meydana gelen farklılıkların gelir tablosu sonucuna nasıl etkide bulunacağı uygulamalı olarak gösterilerek standartlara göre oluşturulan gelir tabloları değerlendirilmiştir. 4.bölüm olan sonuç ve öneriler kısmında ise içerik analizi yöntemi ile tespit edilen farklılık ve benzerlikler özet halinde sunulmuş, yerel muhasebe mevzuatımızın uluslararası standartlara uyumuna yönelik önerilerde bulunulmuştur.

\section{BOBİ FRS STOKLAR STANDARDININ TMS 2 STOKLAR VE VUK STOKLAR MADDELERINE GÖRE KARŞILAŞTIRILMASI}

\subsection{Amaç, Tanım ve Kapsamına Göre Karşılaştırılması}

BOBİ FRS 6.bölüm stoklar standardının amacı; KGK'nın yayımlamış olduğu Büyük ve Orta Boy İşletmeler İçin Finansal Raporlama Standardı Hakkında Tebliğ'in 6.maddesinde belirtilen büyük ve orta büyüklükteki işletmelerin stokları ile ilişkili işlemlerini ortak bir çerçeve halinde düzenlemektir (Ergi ve Güleç, 2019: 378). TMS 2 Stoklar standardının amacı bu standardı uygulayacak işletmeler için stokların ilk satın alınmasından başlayarak dönem sonu mali tablolarında raporlanasıya kadar gerçekleştirilecek tüm muhasebe uygulamalarını düzenlemektir (TMS 2, md: 1). VUK'un amacı ise ülkemizde faaliyet gösteren işletmelerin muhasebe süreçlerinin tek bir düzene göre gerçekleşmesini sağlamak ve faaliyetleri ile ilgili oluşacak vergisel süreçleri düzenlemektir. 
Standartlarda kavramların tanımı yapılırken öne çıkan kavram stoklar olmuştur. Stok kavramı standartlar boyunca aşağıda belirtilen varlıklar için kullanılırken standartlar arasında stok tanımı benzer niteliktedir. VUK'da stok kavramı yerine emtia kavramının sıklıkla kullanıldığı söylenebilir (Selvi ve Ercan, 2018: 48).

- İşletmenin olağan iş akışı çerçevesinde satmak amacı ile elinde bulundurduğu varlıklar yani ticari mallar

- Isşletmenin olağan iş akışı çerçevesinde üretmek için elinde bulundurduğu varlıklar yani yarı mamüller

- İşletmenin olağan iş akışı çerçevesinde üretim ve hizmet süreçlerinde yararlanacağı varlıklar yani ilk madde ve malzemeler.

BOBİ FRS' de stok tanımı ile birlikte net gerçekleşebilir değer tanımına da yer verilmiştir. Net Gerçekleşebilir Değer; işletmenin olağan iş akışı kapsamında, tahmini satış fiyatından tahmini tamamlanma maliyetini ve bu satışı tamamlamak için katlandığı tahmini satış giderlerinin çıkarılmasıyla bulunan tutarı ifade eder (Örten vd., 2008). TMS 2 Stoklar standardında bu kavrama ek olarak gerçeğe uygun değer kavramına da yer verilmiştir.

BOBI FRS stoklar standardı; "Finansal Araçlar ve Özkaynaklar" bölümünde açıklanan finansal araçlar kapsamında olan stoklara ve 'Tarımsal Faaliyetler' bölümüne dahil olan canlı varlık ve hasat zamanındaki tarımsal ürünlere uygulanmayacak olup, diğer kalan işletme stoklarına uygulanacaktır (BOBİ FRS, md: 6.3). TMS 2 Stoklar standardının kapsamına ise TMS 32 Finansal Araçlar: Sunum, TFRS 9 Finansal Araçlar standartlarında açıklanan finansal araçlar ve TMS 41 Tarımsal Faaliyetler standardı kapsamına göre işlem gören canlı varlıklar ve hasat zamanındaki tarımsal ürünler dahil edilmemiştir (TMS 2, md: 2). Ayrıca talep oranı yüksek organize piyasalarda işlem gören veya devletin alım garantisinde bulunan tarım orman ürünleri ile aracılık faaliyeti işi ile uğraşanların ellerinde bulunan stoklar bu standardın kapsamı dışında bırakılmıştır (TMS 2, md: 3). VUK'da stoklarla ilgili yer alan hükümlere, muhasebe kayıt ve düzenini bilanço esasına göre gerçekleştiren tüm gerçek ve tüzel kişiler uymak zorundadır. VUK maddelerinde işletmelerin stokları arasında herhangi bir ayrım yapılmamıştır.

BOBİ FRS stoklar standard1, TMS 2 Stoklar standard1 ve VUK maddelerine göre stokların amaç, tanım ve kapsam açısından birbirleri ile benzer niteliklere sahip oldukları söylenebilir.

\subsection{Stok Maliyetlerinin Hesaplanmasına Göre Karşılaştırılması}

BOBİ FRS'ye göre stoğun satın alma maliyeti, ham madde veya yarı mamülden dönüşme maliyeti ve işletme deposuna giresiye kadar katlanılan diğer maliyetlerden oluşur (BOBİ FRS, md.6.6). Satın alma maliyeti stoğun satın alınması için satıcıya ödenen bedelden oluşurken aşağıda belirttiğimiz maliyetler de stoğun satın alma maliyetine dahil edilecektir (Özerhan ve Sultanoğlu, 2018: 61).

- Stoğun satın alımı esnasında iade alınamayan vergiler

- Stoğun işletme deposuna dahil olasıya kadar gerçekleşen nakliye maliyetleri

- Stoğun satın alınması ile doğrudan bağlantı kurulabilen diğer maliyetler 
Stok eğer ithal ediliyor ise stoğun maliyeti sırası ile; satın alma bedeli, navlun bedeli, limanda yapılan yükleme boşaltma giderleri, gümrük vergisi, konşimento damga vergisi, sigorta giderleri, resmî kurumlarca gerekli görülen test giderleri, antrepo giderleri, yurtiçi nakliye giderlerinden oluşur.

Stokların satın alımı esnasında işletmelerce yapılacak olan ticari iskontolar ve benzer indirim uygulamaları stoğun satın alma maliyetinden düşülür. İşletmeler satın aldıkları stokları muhasebeleştirirken yapılan bu indirim tutarlarını satın alma maliyetinden çıkartarak kayıtlarına dahil ederler (BOBİ FRS, md: 6.7).

Stok maliyetini oluşturan ikinci unsur olan dönüştürme maliyetleri üretim yapan işletmelerde ortaya çıkmaktadır. İlk madde ve malzemelerin üretim sürecine girmesinden başlayarak satış için hazır hale gelesiye kadar mamülle doğrudan bağlantı kurulabilen direkt işçilik giderleri ve üretim giderlerinin toplamı stoğun üretimi için katlanılan dönüştürme maliyetlerini oluştururlar (Toroslu, 2010: 22).

BOBİ FRS'ye göre işletmeler stok dönüştürme maliyetlerinin hesaplanmasında tam maliyet yöntemi veya normal maliyet yöntemlerinden hangi hesaplama yönteminin işletmeleri için uygun olduğunu düşünüyorlarsa inisiyatifleri dahilinde bir tanesini seçip uygulayabilirler (BOBİ FRS, md: 6.12-13).

Stokların maliyetine, ilk madde ve malzeme maliyeti ve dönüştürme maliyetleri dışındaki maliyetler stoğun satışı veya kullanımı için bir konuma getirilmesi, özellik eklenmesi gibi durumlara doğrudan etki eden işlemlerden ortaya çıkıyor ise stoğun maliyetine eklenebilir (Kocamış ve Yıldırım, 2019:61). BOBİ FRS bazı maliyetleri ise stok maliyetine dahil etmeden meydana geldikleri hesap döneminde doğrudan gider olarak işletme finansal tablolarında raporlanmasını istemiştir. Standartda belirtilen bu giderler aşağıdaki gibidir (BOBİ FRS, md: 6.15).

- Ürün imal edildikten sonra ortaya çıkan satış faaliyeti ile ilgili olan giderler

- Yeni bir üretim sürecine dahil olmayacak olan ürünlerin depolama giderleri

- Stokların üretimi ile ilgili olmayan genel yönetim faaliyetlerinden doğan giderler

- Ticaret ve sanayi odaları tarafından sektörel bazda belirlenen ortalama firelerin üzerindeki fire giderleri.

TMS 2 Stoklar standardına göre ise stokların maliyeti; stokların işletme envanterine dahil oluncaya kadar yapılan tüm satın alma maliyetleri, üretim işletmesi ise ilk madde ve malzeme girişi ile başlayıp satılma aşamasına gelesiye kadar yapılan tüm dönüştürme maliyetleri ve satım aşamasına kadar katlanılan diğer maliyetlerden oluşur (TMS 2, md: 10).

TMS 2 Stoklar standardında dönüştürme maliyetlerinin hesaplanmasının normal maliyet yöntemine göre yapılacağı belirtilmiştir (TMS 2, md: 12). Normal maliyet yöntemine göre direkt ilk madde ve malzeme, direkt işçilik ve değişken genel üretim giderlerinin tamamı stoğun maliyetine eklenirken sabit üretim giderleri işletme üretim kapasitesine göre oranlanarak stok maliyetine dahil edilir. İşletmenin üretim kapasitesine göre daha düşük seviyede üretim yapılması halinde ise stok maliyetine dahil edilmeyen sabit giderler ilgili dönemde âtıl kapasite olarak gider yazılır (Büyükmirza, 2012: 500). 
TMS 2 Stoklar standardına göre dönüştürme maliyeti dışında ortaya çıkan diğer maliyetler için yapılacak uygulamalar BOBİ FRS ile aynıdır.

VUK'a göre işletmelerin satın aldıkları değer düşüklüğü statüsünde olmayan ticari mal niteliğindeki stoklarını veya üretim işleminde kullanacakları ilk madde ve malzeme halinde bulunan stoklarını maliyet bedeli ile değerlemeleri gerekmektedir (Taşpınar, 2010: 62). Maliyet bedeli ile değerlenen işletme stoklarının satın alınması sırasında işletmenin ödemiş olduğu tüm giderlerin toplamı stoğun satın alma maliyetini oluşturur (VUK, md: 262).

Stokların işletmeye dahil olması için katlanılan maliyetler; stoğun satın alma tutarı, satın alma esnasında oluşan vergiler ve satın alma sürecinde meydana gelen diğer maliyetlerin toplamidir (Ergin, 2016: 16).

VUK'un 275.maddesi incelendiği takdirde tam maliyet yönteminin stok maliyeti hesaplama yöntemi olarak kullanılması gerektiğini anlayabiliriz (Marşap ve Barışçı, 2014: 2). Ülkemizde tam maliyet yöntemi uygulaması benimsenmiş olup vergi mevzuatı açısından bu yöntemin kullanılması yönünde herhangi bir sakınca bulunmamaktadır (Özerhan ve Yanık, 2015: 138).

$\mathrm{Bu}$ açıklamalara göre ele alınan standartlar arasında stokların ilk satın alım işlemleri arasında uyum olduğu sonucuna ulaşılırken, stok maliyetlerinin hesaplanması sırasında kullanılması gereken yöntemler açısından farklılıkların bulunduğu sonucuna ulaşılmıştır.

\subsection{Finansman Giderlerinin ve Maliyetlerinin Durumuna Göre Karşıllaştırılması}

Vade farkı ve kur farkı gibi gider unsurları işletmelerin ihtiyaçları olan finansman kalemlerini kendi öz kaynakları dışından karşılandığı durumlarda ortaya çıkan giderler ve maliyetlerdir (Elagöz ve Özcan, 2020: 78).

BOBİ FRS'nin 6.8'inci maddesine göre stoğun satın alma maliyetinin hesaplanmasında ödeme koşulu satın alma maliyetini değiştiren bir unsur olarak göze çarpmaktadır. Vadeli stok alımında, ödeme süresinin bir yıldan kısa ya da uzun olmasına göre stoğun satın alma maliyetine dahil edilip edilmeyeceği belirtilmiştir. Ödeme süresine göre işlemler aşağıda belirtildiği şekilde yapılacaktır (Selvi ve Ercan, 2018: 49).

- Ödeme süresi bir yılın altında ise: Standardın 6.8'nci maddesinde “Bir yıl veya daha kısa vadeli bir ödeme karşılığında satın alınan stoklar vade farkı ayrıştırılmaksızın, ödenen veya ödenmesi beklenen nakit tutar üzerinden ölçülür" ifadesine yer verilmiştir. Buna göre stoğun satın alımı esnasında ödeme süresi için bir yıldan daha az bir süre belirlenmiş ise finansman giderleri ilgili dönemde giderleştirilmeden stoğun satın alma maliyetine eklenilmelidir.

- Ödeme süresi bir yılın üstünde ise: Standardın 6.8'nci maddesinde “Bir yıldan uzun vadeli bir ödeme karşılığında satın alınan stoklar vade farkı ayrıştırılarak peşin fiyat üzerinden ölçülür" ifadesine yer verilmiştir. Standardın bu hükmüne göre işletme finansman giderini stoğun satın alma maliyetine dahil etmeden "328 Ertelenmiş Vade Farkı Giderleri” hesabına kaydedecek ve ilgili dönemlerde gider olarak kayıtlarına yansitacaktır. Stoğun satın alma maliyetine ise ilgili stoğun peşin olarak alınması durumunda ödenmesi gereken tutar dahil edilecektir.

İşletmeler stok satın alımı ile ilgili ödemeyi bir yıldan daha fazla bir sürede gerçekleştirecekler ise ortaya çıkan finansman giderini BOBİ FRS 9 Finansal Araçlar ve 
Özkaynaklar bölümünde açıklanan Etkin Faiz Yöntemi (EFY)'ye göre hesaplayarak faiz gideri hesabına kaydedeceklerdir (BOBİ FRS, md: 6.8).

EFY, kaynak yaratmak amacı ile kullanılan finansman araçlarının üzerinde bulunan maliyet unsurlarının hesaplanması ve hesaplama işlemleri sonucunda tespit edilen maliyetlerin dönemler itibari ile kayıtlara alınması yöntemidir (Kaya, 2015:107). EFY' de Etkin Faiz Oranı (EFO) kullanılarak finansman araç tutarlarının indirgenmiş bugünkü değere ulaştırılması sağlanmaktadır.

Stoğun satın alınması durumunda ortaya çıkacak olan kur farkları gider olarak kayıtlara alınırken, stok "özellikli varlık" statüsünde olup satışa hazır hale gelmesi için bir yıldan daha uzun bir süreye ihtiyaç var ise stok maliyetine dahil edilecektir (Karacan vd., 2018: 8).

TMS 2 Stoklar standardının 18.maddesine göre; anlaşma peşin alım fiyatı ile ödenen fiyat arasında bir fark olan finansman unsuru içerdiği takdirde, bu unsurlar finanse edildiği dönemde faiz gideri olarak muhasebeleştirilir. Dönem gideri olarak muhasebeleştirilecek tutar ise TFRS 9 Finansal Araçlar standardında belirtilen EFY'ye göre hesaplanacaktır (TMS 23, md: 6). Buradaki tek istisnai durum ise 23 Nolu Borçlanma Maliyetleri standardında belirtilen özellikli varlık statüsünde olan stoklar konusundadır.

Stok eğer özellikli bir varlık durumunda ise bu stoğun elde edinme, üretim ve inşası ile doğrudan bağlantı kurulabilen borçlanma maliyetleri stoğun maliyetine dahil edilir. Doğrudan bağlantı kurulamayan borçlanma maliyetleri ise ilgili dönemde gider olarak kayıtlara alınır (TMS 23, md: 1). Özellikli varlılar ancak uzun sayılabilecek bir süre zarfından sonra satışa veya kullanıma hazır hale gelebilen varlıklardır (TMS 23, md: 5).

TMS 2 Stoklar standardına göre stokların edinimi esnasında ortaya çıkan kur farklarında TMS 21 Kur Değişiminin Etkileri standardına göre işlem yapılacaktır. Bu standarda göre stoklar satın alma olayının gerçekleştiği günün kuru kullanarak kayıtlara intikal ettirilecek, bu tarihten sonra meydana gelen kur farkları ise stok maliyetine eklenmeden gider olarak kayıtlara alınacaktır (Avcı ve Avcı, 2016: 81).

Stok satın alımı işlem sürecinde meydana gelen, finansman maliyetleri olarak ortaya çıkan kur ve vade farklarının satın alınan stoğun maliyet bedeline dahil edilmesi VUK'a göre uygundur (Gönen ve Demir, 2012: 165). Finansman giderlerinin stok maliyetine eklenmesi durumunu VUK'un 262. Maddesinde yapilan maliyet bedeli tanımı da desteklemektedir. Satın alınan stoğun yapılması gereken ödemesinin yapılmayıp ödemenin sonraki bir tarihte gerçekleşmesinden kaynaklanan vade farklarının stoğun maliyetine eklenmesi gerekmektedir (Kara, 2019: 33). Stokların işletme deposuna dahil olasıya kadar gerçekleşen borçlanma maliyetlerinin stoğun maliyetine dahil edilmesi gerektiği daha sonrasında meydana gelecek olan borçlanma maliyetlerinin ise tercihe göre stok maliyetine dahil edilebileceği veya maliyetin oluştuğu dönemde gider olarak kayıtlara alınabilir (Ergin, 2016: 18). Vade farkları da bir nevi borçlanma aracı konumunda olduğundan dolayı stokların işletme envanterine dahil olasıya kadar oluşan vade farkı ödemeleri stoğun maliyetine eklenmesi daha sonrasında oluşan vade farkı maliyetlerinin ilgili dönemde gider olarak kayıtlara dahil edilmesi işletmeler açısından uygulanabilecek bir yöntem olduğunu söyleyebiliriz. 
Kur farklarının stok satın alımı sürecinde oluşması durumunda işletmeler malın maliyetini hesaplama işlemine ortaya çıkan kur farklarını dahil edeceklerdir. Stoklarda daha sonradan kur farkı oluşması durumunda ise şirketler ilgili dönemde gider hesaplarına bu maliyetleri yansitabilecek ya da stoğun maliyetine dahil edebileceklerdir (238 Sira Nolu Vergi Usul Kanunu Genel Tebliği, 1995).

İlgili açıklamalara göre BOBİ FRS stoklar standardı, TMS 2 Stoklar standardı ve VUK maddelerine göre finansman gider ve maliyetleri ile ilgili uygulama farklılıklarının bulunduğu sonucuna ulaşılmıştır.

\subsection{Stok Maliyetlerinin Ölçüm Tekniklerine Göre Karşılaştırılması}

BOBİ FRS 6.Bölüm Stoklar standardına göre işletmelerin stoklarının maliyetleri hesaplanırken fiili maliyet yöntemine göre gerçekleşen maliyet tutarları dikkate alınarak işlem yapılır. Standarda göre maliyet ve perakende maliyet yöntemlerinin kullanılabilmesi için belirlenen stok maliyetlerinin fiili maliyet yöntemine göre tespit edilen tutara yaklaşık bir tutarda olması gerekmektedir (BOBİ FRS, md: 6.19).

TMS 2 Stoklar standardında sonuçların maliyete yakın olması şartı ile standart maliyet yöntemi ve perakende yöntemi tekniklerinin kullanılmasına izin verilmiştir (TMS 2, md: 21). Standardın 21.maddesinde geçen "sonuçların maliyete yakın olması" ifadesi fiili maliyet yöntemini ifade etmektedir. Bu durumda fiili, standart ve perakende maliyet yöntemleri TMS 2 Stoklar standardına göre kullanılabilecektir.

Stok ölçüm tekniği olarak VUK'da kesin bir şekilde terimsel olarak hangi ölçüm tekniğinin uygulanması gerektiği belirtilmemiştir ancak Maliye Bakanlığı'nın fiili maliyet ölçüm tekniğinin uygulanmasını desteklediği bilinmektedir (Demir, 2019: 251).

$\mathrm{Bu}$ açılamalara göre stok maliyetlerinin ölçüm tekniği olarak fiili maliyet yönteminin kullanılması her üç durumda da en doğru yöntem olarak karşımıza çıkmaktayken BOBİ FRS stoklar ve TMS 2 Stoklar standartlarında alternatif yöntemler sunulmuş bulunmaktadır. Buna göre kullanılması tavsiye edilen stok maliyet ölçüm tekniği açısından ele alınan standartlardaki uygulamalar birbirleri ile benzer niteliktedir.

\subsection{Stok Maliyetlerini Hesaplama Yöntemlerine Göre Karşılaştırılması}

BOBİ FRS'ye göre birbirinin yerine kullanılamayan stoklar ile belirli projelerde kullanılmak üzere imal edilen stokların maliyet değeri bulunurken her bir stok kaleminin maliyet değeri birbirinden bağımsız olarak tespit edilir (BOBİ FRS, md: 6.21). Standardın bu maddesinde belirtilen stoklar için işletmelerin "Gerçek Parti Maliyet Yöntemi" ni kullanabileceklerini ifade edebiliriz. BOBİ FRS'ye tabi işletmeler diğer stokları için ilk giren ilk çıkar (FIFO) veya işletmeye uygun olan ağırlıklı ortalama maliyet yöntemlerinden bir tanesini seçerek stok maliyetlerini hesaplama yöntemi olarak uygulayabilir. İşletmelerde eğer kullanım amacı ve özellikleri farklı olan stoklar mevcut ise standartda birden fazla stok maliyet hesaplama yönteminin kullanılmasına izin verilmiştir. İşletmeler, son giren ilk çıkar (LIFO) uygulamasını stokları için kullanamayacaklardır (BOBİ FRS, md: 6.20).

TMS 2 stoklar standardında stok maliyetlerini hesaplama yöntemleri 5 paragraf halinde açıklanmış olup, stok maliyet hesaplamalarında kullanılabilecek yöntemler; gerçek parti maliyet yöntemi, FIFO ve ağırlıklı ortalama maliyet yöntemi olarak belirlenmiştir (TMS 2, 
md: 24-26). Literatürde stok maliyetlerini hesaplama yöntemi olarak geçen ve finansal tablolar üzerindeki enflasyon etkisini azaltıcı yöntemlerden birisi olarak bilinen son LIFO uygulamasına TMS 2 stoklar standardında izin verilmemiştir (Sönmez, 2007: 156).

VUK'a göre kullanılacak yöntemlere bakarsak işletmelerin kullanmaları gereken yöntemin açıcça belirtilmediğini görebiliriz (VUK, md: 275). Yayımlanmış olan 176 Sıra Nolu VUK Genel Tebliği'nde ise VUK 262.maddeye atıf yapılarak işletmelerin iktisadi varlıklarının maliyetlerini hesaplamada fiili maliyet yöntemini kullanmaları istenmiştir. Fakat işletmeler stoklarını gerçek parti maliyet yöntemine göre tespit edemiyorlar ise ortalama maliyet yöntemini kullanmalarında herhangi bir sakınca yoktur. Ortalama maliyet yöntemi işletmeler tarafından gerçek parti maliyet yönteminin uygulanamadığı durumlarda alternatif yöntem olarak kullanılabilmektedir (Akyol, 2019: 59). Gelir İdaresi Başkanlığı tarafından yayımlanan bir özelgede de FIFO yönteminin özelgeyi talep eden işletme tarafından kullanılması uygun görülmüştür (GİB Maliyet Hesaplama Yönteminde Değişiklik Yapılması Hakkında Özelge, 2017). LIFO yöntemi vergi mevzuatımızda ilk önce 4008 sayılı kanun ile uygulanabilir hale gelmiş daha sonrasında 5024 sayılı kanun ile uygulamadan kaldırılmıştır (Akyol, 2019: 58). Yayımlanan özelge ve tebliğler ışığında gerçek parti maliyet, FIFO ve ağırlıklı ortalama maliyet yöntemleri VUK'a göre uygulanabilir.

BOBİ FRS stoklar standard1, TMS 2 Stoklar standardı ve VUK stoklar ile ilgili maddelere göre işletmelerin stok maliyetlerini belirleme yöntemi olarak kullanacakları hesaplama şekli birbirleri ile uyumlu olup benzerlik göstermektedir.

\subsection{Stoklarda Değer Düşüklüğü Durumuna Göre Karşılaştırılması}

BOBİ FRS'ye tabi işletmeler her dönem sonunda stoklarında değer düşüklüğü durumunun olup olmadığını kontrol etmeli, stokların net gerçekleşebilir değerini hesaplayıp defter değeri ile karşılaştırmalıdırlar (Kaya, 2018: 278). Değer düşüklüğü durumunun tespiti halinde işletmeler stokların değerlerini (muhasebe kayıtlarında yer alan defter değeri) hesaplanan net gerçekleşebilir değer ile değiştirerek finansal tablolarında raporlamalıdırlar. Defter değeri ile net gerçekleşebilir değer arasındaki fark değer düşüklüğü zararıdır. Değer düşüklüğü zararının ilgili dönemin gelir tablosunda satışların maliyeti bölümünde raporlanması gerekmektedir (BOBİ FRS, md: 6.22). Her dönem sonunda değer düşüklüğü zararı için karşılık ayrılması gerekmektedir. KGK tarafından yayınlanan taslak hesap planında değer düşüklüğünün gider olarak yazılıp takip edilebilmesi için "626 Stok Değer Düşüklüğü Karşılık Giderleri (-)" hesabına yer verilmiş olup hesaplanan değer düşüklüğü karşılık tutarı bu hesabın borcuna, "158 Stok Değer Düşüklüğü Hesabı'nın alacağına kaydedilmesinin gerektiği belirtilmiştir. İşletmeler değer düşüklüğüne uğrayan ve sonucunda değer düşüklüğü karşılığı ayırıp işletme bilançosunda takip ettikleri stokları için yeni raporlama tarihlerinde tekrar değer düşüklüğü testi yapmalılardır (BOBİ FRS, md: 6.25). Yapılan değer düşüklüğü testinin sonucunda ayrılan karşılığın iptal edilmesi gerekiyor ise taslak hesap planında yer alan "627 Stoklara İlişkin Konusu Kalmayan Karşılıklar (+)" hesabı kullanilacaktır (kgk.gov.tr, 2020).

TMS 2 Stoklar standardında; "Stoklar, maliyet ve net gerçekleşebilir değerin düşük olanı ile değerlenir" ve "Stoklar mali tablolarda, kullanımları veya satılmalar sonucunda elde edilmesi beklenen tutardan daha yüksek bir bedelle izlenemez" ifadelerine yer verilerek BOBİ FRS'de 
izlenen değer düşüklüğü uygulamasının aynı şekilde TMS 2 Stoklar standardında da yer aldığını söyleyebiliriz (TMS 2, md: 9-28).

VUK'da stok değer düşüklüğü VUK'un 274. Maddesinde ele alınmış, işletme stoklarının değerleme işleminin yapılacağı zamandaki değerlerinde maliyet bedellerine göre \%10 veya daha fazla azalma meydana geldiğinin tespit edilmesi halinde maliyet bedeli yerine emsal bedeli dikkate alınması gerektiği belirtilmiştir. "Emsal Bedeli gerçek bedeli olmayan veya bilinmeyen veyahut doğru olarak tespit edilemeyen bir malın, değerleme gününde satılması halinde nazaran haiz olacağ̆ değerdir" (VUK, md: 267). Emsal bedeline göre işlem yapılacakken VUK 267.madde de belirtilen maliyet bedeli esası uygulanmayacak, ortalama fiyat esası ve takdir esası yöntemleri dikkate alınacaktır (VUK, md: 274).

BOBİ FRS stoklar ve TMS 2 Stoklar standartlarına göre stoklarda değer düşüklügünün yaşanması durumunda uygulanması gereken yol benzerdir. VUK stoklar ile ilgili maddelere göre stoklarda değer düşüklüğü durumunun meydana gelmesi halinde değer tespit amac1 diğer standartlar ile uyumlu iken uygulama süreci farklılık göstermektedir.

\subsection{Stokların Gider Olarak Kayıtlara Alınmasına Göre Karşılaştırılması}

BOBİ FRS'de stokların satış işlemi gerçekleştiği anda stokların kayıtlı olduğu defter değeri, satış gelirinin finansal tablolara dahil edildiği dönemin gelir tablosunda raporlanır (BOBİ FRS, md.6.26). Elden çıkartılan stoklar için herhangi bir değer düşüklüğü karşılığ1 hesaplanarak muhasebe kayıtlarında izlenmiş ise stokların satış işlemi gerçekleştiğinde veya işletme içi kullanımına aktarıldığı sırada ayrılan karşılıkta iptal edilecektir (Karapınar ve Eflatun, 2019: 141). Stokların işletme içerisinde kullanılması söz konusu olduğunda stoğun maliyeti duran varlıkların maliyetine eklenebilir. Bu durumda stoğun maliyeti dahil olduğu duran varlığın amortisman süresi boyunca dönemler halinde gider olarak kayıtlara alınır (BOBİ FRS, md: 6.27).

TMS 2 Stoklar standardına göre işletmenin sahip olduğu stokların satışı tamamlandığında işletmede kayıtlı olduğu değer ile gider olarak finansal tablolarda raporlanmalıdır. Stok değerlerinde meydana gelen azalmalar ve stok değerini net gerçekleşebilir değere getiren stok değer düşüklüğü unsurları, bu durumun gerçekleştiği dönemde finansal tablolarda gider olarak raporlanmalıdır. İşletmenin değer düşüklüğü tahminine göre ayrılan ancak tahminlerin doğrultusunda gerçekleşmeyen, iptal edilmesi veya azaltılması gereken değer düşüklüğü karşılıkları iptal işleminin gerçekleştiği dönemde satılan malın maliyeti hesabını düşürecek şekilde kayıtlara alınması gerekmektedir (TMS 2, md: 34). İşletmenin sahip olduğu stokların işletme dahilinde üretim amacı dışında kullanılması halinde dönüştüğü varlıkla ilgili olan hesaba devredilip, bu ürün için yasal olarak kabul edilen yıpranma payı süresi boyunca gider olarak kayıtlara alınması gerekmektedir (TMS 2, md: 35).

VUK'a göre belirlenen stok maliyetleri satış işleminin gerçekleştiği dönemde gider olarak kayıtlara dahil edilir. Satış işlemi dışında işletme içerisinde kullanmak istedikleri bu stokları ilgili gider hesaplarına yansıtarak kaydedebilirler (Sayın, 2001: 38). İlk olarak maliyet bedeli ile değerlenen işletme stoklarının değer düşüklüğü durumunun meydana gelmesi sonucu emsal bedeli yöntemi ile yeniden tayin olması durumunda ortaya çıkan stok değer düşüklüğü tutarı “654 Karşılık Giderleri Hesabı” kullanılarak ilgili dönem gideri olarak kayıtlara alınır (Fidan, 2019: 57). 
$\mathrm{Bu}$ açıklamalar göre ele alınan BOBİ FRS stoklar, TMS 2 Stoklar ve VUK stoklar ile ilgili uygulamaların birbiri ile benzer nitelikte olduğu sonucuna varılabilir.

\subsection{Stok Satış İşlemlerinde Finansman Unsuru Durumuna Göre Karşılaştırılması}

BOBİ FRS'nin Hasılat bölümünde stokların satış işlemleri ile ilgili yapılacak uygulamalar belirlenmiştir. Vadeli satış işlemlerinde vade süresinin 1 yıl veya daha az olması durumunda vade farkı ayrıştırılmadan satışa konu olan tutar gelir olarak kayıtlara alınmalı, 1 yıl ve üzeri vadenin söz konusu olması halinde ise vade farkı " 480 Ertelenmiş Gelirler" hesabında izlenerek bilançoda raporlanmalıdır. Daha sonrasında döneme isabet eden vade farkı tutarı EFY'ye göre hesaplanıp faiz geliri olarak gelir tablosuna yansitılmalıdır (BOBİ FRS, md: 5.9).

TMS'ye göre stokların satış işlemleri finansman unsuru içerdiği takdirde muhasebe uygulamaları TMS 39 Finansal Araçlar: Muhasebeleştirme ve Ölçme standardına göre yapılacaktır. Stokların peşin satış tutarı ile vadeli satış tutarı arasında fark oluşması durumunda vade süresi gözetilmeksizin vade farkı ayrıştırılacak, TFRS 9 Finansal Araçlar standardında belirtilen EFY'ye göre döneme isabet eden vade farkı tespit edilip, BOBİ FRS'de olduğu gibi kayıtlara alınacaktır.

VUK'a göre stok satış işlemlerinde herhangi bir finansman unsurunun olup olmadiğına bakılmaksızın satış işlemine konu olan toplam bedel doğrudan dönem geliri olarak gelir tablosuna yansitilir (VUK, md: 281).

Stok satış işlemlerine finansman unsurunun dahil olması durumundaki uygulamalar BOBİ FRS Stoklar, TMS 2 Stoklar ve VUK stoklarla ilişkili maddelere göre farklılık göstermektedir.

\subsection{Diğer Ortaya Çıkan Durumlara Göre Karşılaştırılması}

Hizmet işletmelerinde ortaya çıkan stoklar ile ilgili durumları inceleyecek olursak BOBİ FRS'ye göre stokların maliyeti hizmetin meydana gelmesinde birinci dereceden katkısı olan maliyetlerden oluşur. Doğrudan ilişkili olmayan maliyet unsurları dönem gideri olarak kayıtlara alınır (BOBİ FRS, md: 6.17). Hizmetin bir hesap döneminde tamamlanamaması durumunda hizmet üretimi ile doğrudan ilişkili maliyetler hasılat meydana gelesiye kadar dönem sonunda aktifleştirilerek bilançoda gösterilmelidir (Selvi ve Ercan, 2018: 53). Hizmet işletmelerinde stoklar ile ilgili işlemlerde TMS 2 Stoklar standardı BOBİ FRS ile tam uyumludur. BOBİ FRS' de olduğu gibi doğrudan ilişkili maliyetler hasılatın gerçekleşmesine kadar bilançoda takip edilip hasılatın gerçekleşmesi ile birlikte gelir tablosunda raporlanır (TMS 2, md: 19). VUK'a göre ise hizmet üretimi ile ilgili maliyetler hasılat işleminin gerçekleşmesi beklenmeden meydana geldikleri dönemin gelir tablosunda raporlanmalıdır (Kabataş ve Pamukçu, 2010: 193-199).

Canlı varlık olarak tanımlanan ve hasadı yapılan stokların standartlar karşısındaki durumları incelendiği takdirde BOBİ FRS'ye göre bu stokların maliyet ölçümünde gerçeğe uygun değer kullanılır ve stokların işletme envanterine alınması esnasında oluşan kar ya da zararlar dönem sonu mali tablolarında raporlanır (BOBİ FRS, md: 7.5-7). TMS 2 Stoklar standardı TMS 41 Tarımsal Faaliyetler standardının dikkate alınması gerektiğini belirtmiştir. Canlı varlıkların hasadı sonucu elde edilen stoklar satış maliyetlerinden arındırılmış gerçeğe uygun değer üzerinden hesaplanarak işletme stoklarına dâhil edilmelidir. Bu değere hasat zamanında ortaya çıkan maliyet de denilebilir (TMS 2, md: 20). VUK'a göre ziraat işi ile iştigal olan firmalarda hayvanlar ve tarım ürünleri maliyet bedeli ile değerlenerek muhasebe 
kayıtlarına dâhil edilir. İşletme envanterine dâhil olan hayvanların maliyet bedeli tespit edilemiyorsa emsal bedeli yönteminin kullanılması gerekmektedir (VUK, md:276,277).

İşletmelerde ortak ve yan ürünlerin üretimi söz konusu ise BOBİ FRS'ye göre ortak ürünler için nispi satış değer yöntemi uygulanmalı, yan ürünler ise net gerçekleşebilir değeri tespit edilerek ana ürün maliyetinden çıkartılmalıdır. TMS 2 Stoklar standardına göre ortak ve yan ürünlerin maliyeti BOBİ FRS'de yer alan uygulama ile uyumlu şekildedir (Yalçın, 2019: 208). VUK'a göre ortak ürünlerin maliyeti konusunda herhangi bir açılama yapılmamış olup normal stoklardan farksız olarak maliyet bedelleri ile değerlenecektir (VUK, md:274-275). Yan ürünlerin maliyeti ise emsal bedel yöntemi ile tespit edilir (VUK, md:278).

\section{FINANSMAN UNSURLARINDAKI FARKLILIKLAR ÜZERINE BİR UYGULAMA}

BOBI FRS, TMS 2 Stoklar ve VUK'da yer alan stoklar ile ilgili maddelere göre standartların farklılıklarını incelediğimizde finansman unsurları, maliyet hesaplama yöntemleri ve hizmet sunan işletmelerdeki stok satışının gelir olarak yansıtılması durumlarında farklılıkların olduğu sonucuna ulaşmaktayız. Aşağıdaki örnek olay ile birlikte finansman unsurları ile ilgili işlemlerin bu üç yönteme göre nasıl yapılacağını, etkin faiz yönteminin nasıl uygulanacağını ve bu işlemlerin işletmenin gelir tablosuna nasıl etki edeceğini inceleyeceğiz.

Örnek Olay 1: ABC A.Ş. 11.01.2020 tarihinde peşin fiyatı 340.000,00 TL olan Ticari Malı 210 gün vadeli olmak koşulu ile 350.000,00 TL+ \%18 KDV'ye satın almıştır.

BOBİ FRS kapsamında yapılacak yevmiye kaydında ticari malın vade süresi 210 gün olarak belirlendiğinden ve standardın 6.8'nci maddesinde vade sürelerinin 1 yllın altında olduğunda vade farkı ayrıştırılmaması gerektiğinden dolayı ticari mal satın alma işlemi aşağıdaki gibi yapılacaktır.

\begin{tabular}{|c|c|c|}
\hline $\begin{array}{l}153 \text { TICARI MALLAR HS } \\
191 \text { İNDİRILECEK KDV HS }\end{array}$ & $\begin{array}{l}\text { Borç } \\
350.000,00 \\
63.000,00\end{array}$ & $\begin{array}{l}\text { Alacak } \\
413.000,00\end{array}$ \\
\hline -Ticari Mal Satın Alım Kaydı- & & \\
\hline
\end{tabular}

TMS 2 Stoklar Standardının 18.maddesinde belirtildiği üzere peşin alım fiyatı ile ödenen fiyat arasında fark bulunması durumunda herhangi bir vade süresi aranmaksızın aradaki fark dönem gideri olarak kayıtlara alınacaktır. Dönem gideri olarak kayıtlara alınacak finansman tutarı ise TFRS 9 Finansal Araçlar standardında belirtilen EFY'ye göre belirlenecektir. TMS 2 Stoklar Standardına göre yapılması gereken kayıt ve EFY'ye göre hesaplama aşağıdaki gibidir.

\begin{tabular}{|c|c|c|}
\hline $\begin{array}{l}153 \text { TİCARİ MALLAR HS } \\
191 \text { İNDIRILECEK KDV HS } \\
328 \text { ERTELENMIŞ VADE FARKI GIDERLERİ HS (-) }\end{array}$ & $\begin{array}{l}\text { Borç } \\
340.000,00 \\
63.000,00 \\
10.000,00\end{array}$ & Alacak \\
\hline -Ticari Mal Satın Alım Kaydı- & & \\
\hline
\end{tabular}


Peşin Fiyat: 340.000,00 TL 210 Gün Vadeli Fiyat: 350.000,00 TL

$\mathrm{EFO}=($ Vadeli Fiyat $/$ Peşin Fiyat $)-1$

EFO (210 Gün İçin $)=(350.000,00$ TL/340.000,00 TL $)-1=0,029$

EFO (365 Gün İçin $)=\left((1+0,029)^{\left(\frac{365}{210}\right)}\right)-1=0,05$

Gelecek Değer $=$ Peşin Değer $\times(1+\text { Faiz Oranı })^{\text {Zaman }}$

$$
\begin{aligned}
& =340.000,00 \mathrm{TL} \times(1+0,05)^{\left(\frac{20}{365}\right)} \\
& =340.910,18 \mathrm{TL}
\end{aligned}
$$

Döneme İsabet Eden Vade Farkı Gideri $=340.910,18 \mathrm{TL}-340.000,00 \mathrm{TL}=910,18 \mathrm{TL}$

EFY'ye göre yapılan hesaplama sonucu ilgili döneme isabet eden finansman tutar1 910,18 TL olarak bulunmuş ve dönem sonunda aşağıda belirtilen muhasebe işlemi ile gider olarak kayıtlara alınmıştır.

\begin{tabular}{|c|l|l|}
\hline $\begin{array}{c}\text { 780 FINANSMAN GIDERLERI HS } \\
\text { 328 ERTELENMIŞ VADE FARKI GIDERLERİ HS } \\
\text {-Vade Farkı Gider Kaydı- }\end{array}$ & $\begin{array}{l}\text { Borç } \\
910,18\end{array}$ & Alacak \\
\hline
\end{tabular}

VUK'un 262.maddesinde yapılan maliyet bedeli tanımından ticari malların satın alınması durumunda oluşan finansman maliyetlerinin ticari mal maliyetine eklenmesinin doğru olduğu sonucu ortaya çıkmaktadır. VUK'a göre yapılması gereken işlem bu açılamaya göre yapılacak olup vade süresi dikkate alınmadan toplam satın alma tutarı 153 Ticari Mallar

\begin{tabular}{|c|c|c|}
\hline $\begin{array}{l}153 \text { TİCARİ MALLAR HS } \\
191 \text { İNDİRİECEK KDV HS }\end{array}$ & $\begin{array}{l}\text { Borç } \\
350.000,00 \\
63.000,00\end{array}$ & $\begin{array}{l}\text { Alacak } \\
413.000,00\end{array}$ \\
\hline - Ticari Mal Satın Alım Kaydı- & & \\
\hline
\end{tabular}
hesabının borcuna yazılacaktır.

Örnek Olay 2: ABC A.Ş. 11.01.2020 tarihinde satın almış olduğu stokları peşin fiyatı 960.000,00 TL'den satmaya planlamaktadır. Ancak 21.01.2020 tarihinde 540 gün vadeli olacak şekilde 1.080.000,00 TL + \%18 KDV'den satış işlemini gerçekleştirmiştir.

BOBİ FRS’ye göre satış işlemi gerçekleşen ve vadesi 1 yıl üzeri olan stokların hasılat kaydı vade farkı ayrıştırılarak peşin tutar üzerinden ölçülür. Stoğun peşin satış tutarı dönem gelir tablosunda raporlanırken finansman tutarı "480 Ertelenmiş Gelirler" hesabında izlenir. Dönemlere isabet eden finansman farkları EFY'ye göre tespit edilip faiz geliri olarak kaydedilir. Buna göre yapılması gereken stok satış kaydı aşağıdaki gibi gerçekleşecektir. 


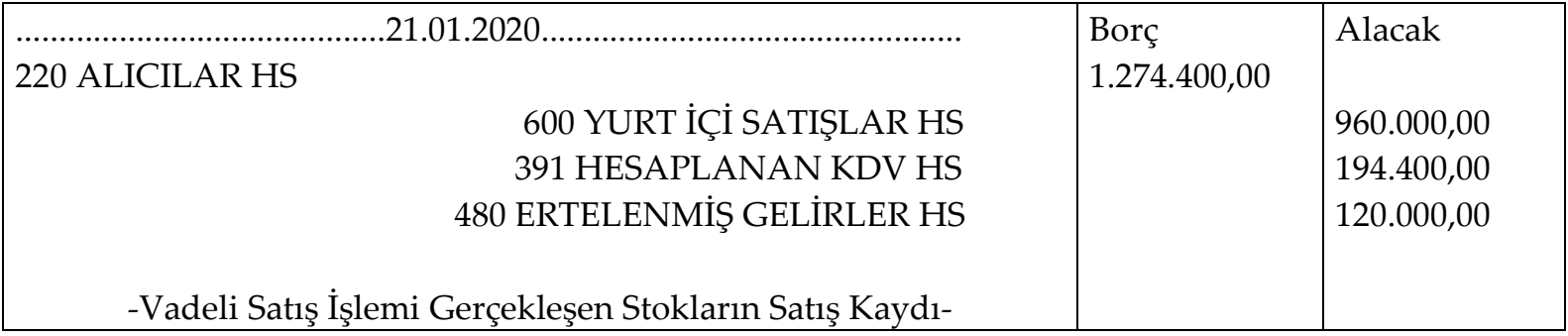

Stoğun satış işlemi ile birlikte maliyet kaydı da yapılmalı 11.01.2020 tarihinde belirlenen tutar "621 Satılan Ticari Malların Maliyeti" hesabına kayıt edilmelidir.

\begin{tabular}{|c|l|l|}
\hline 621 SATILAN TİCARİ......................21.01.2020......................................... & Borç & Alacak \\
- Satılan MİCARİ MALLAR HS & $350.000,00$ & \\
\end{tabular}

Peşin Fiyat: $960.000,00 \mathrm{TL} \quad 540$ Gün Vadeli Fiyat: $1.080 .000,00 \mathrm{TL}$

$\mathrm{EFO}=($ Vadeli Fiyat $/$ Peşin Fiyat $)-1$

EFO $(540$ Gün İçin $)=(1.080 .000,00 \mathrm{TL} / 340.000,00 \mathrm{TL})-1=0,125$

$\mathrm{EFO}(365$ Gün İçin $)=\left((1+0,125)^{\left(\frac{365}{540}\right)}\right)-1=0,08$

Gelecek Değer $=$ Peşin Değer $\times(1+\text { Faiz Oranı })^{\text {Zaman }}$

$$
\begin{aligned}
& \left.=960.000,00 \mathrm{TL} \times(1+0,08)^{\left(\frac{10}{365}\right)}\right) \\
& =962.026,32 \mathrm{TL}
\end{aligned}
$$

Döneme İsabet Eden Vade Farkı Geliri $=962.023,32 \mathrm{TL}-960.000,00 \mathrm{TL}=2.026,32 \mathrm{TL}$

EFY'ye göre yapılan hesaplama sonucu ilgili döneme isabet eden finansman geliri 2.026,32 TL olarak tespit edilmiştir. Bu tutar öncelikle kısa dönem ertelenmiş gelirler hesabına intikal ettirilmeli daha sonrasında faiz geliri olarak kayda alınmalıdır.

\begin{tabular}{|c|c|c|}
\hline 380 ERTELENMIŞ GELİRLER HS & $\begin{array}{l}\text { Borç } \\
2.026,32\end{array}$ & $\begin{array}{l}\text { Alacak } \\
2.026,32\end{array}$ \\
\hline -Faiz Gelirinin Gelirler Hesabına Alınması Kaydı- & & \\
\hline
\end{tabular}

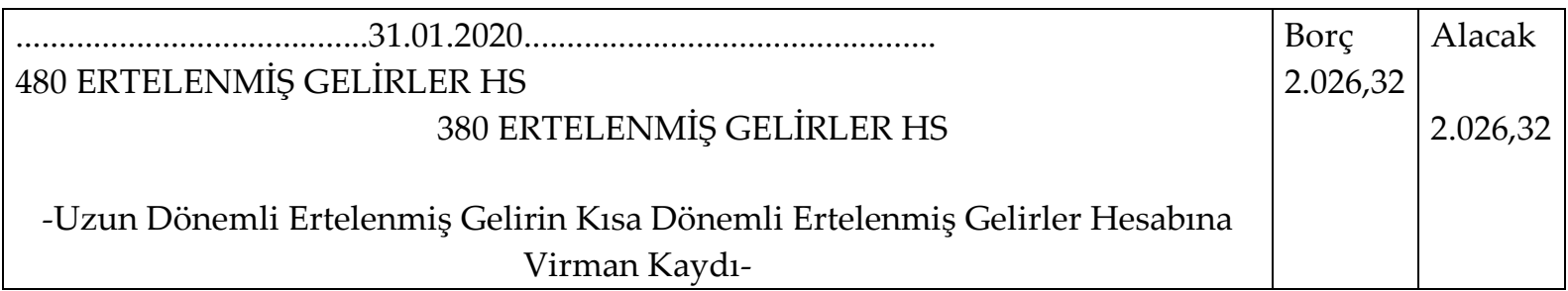


TMS 2 Stoklar standardına göre yapılması gereken işlemler BOBİ FRS ile birebir uyumludur. Peşin satış tutarı dönem geliri olarak kayda alınırken finansman unsuru bilançoda 480 Ertelenmiş Gelirler hesap kaleminde takip edilmelidir.

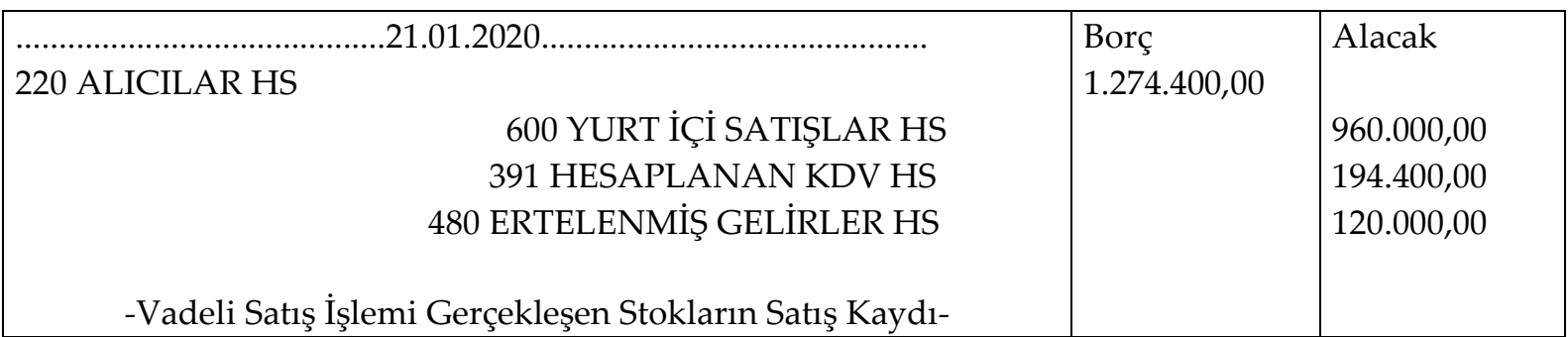

Stoğun satış işlemi ile birlikte maliyet kaydı da gerçekleştirilmeli 11.01 .2020 tarihinde belirlenen tutar “621 Satılan Ticari Malların Maliyeti” hesabına kayıt edilmelidir.

\begin{tabular}{|c|c|c|}
\hline $\begin{array}{r}621 \text { SATILAN TİCARİ MALLLARIN MALİYETİ HS } \\
153 \text { TİCARİ MALLAR HS }\end{array}$ & $\begin{array}{l}\text { Borç } \\
340.000,00\end{array}$ & $\begin{array}{l}\text { Alacak } \\
340.000,00\end{array}$ \\
\hline - Satılan Malın Maliyeti Kaydı- & & \\
\hline
\end{tabular}

Daha önce EFY'ye göre hesaplanmış olan tutar öncelikle kısa dönem hesap kalemine alınmalı daha sonrasında ise dönem faiz geliri olarak gelir tablosuna yansıtılmalıdır.

\begin{tabular}{|c|c|c|}
\hline 480 ERTELENMIŞ GELİRLER HS & $\begin{array}{l}\text { Borç } \\
2.026,32\end{array}$ & Alacak \\
\hline $\begin{array}{l}380 \text { ERTELENMIŞ GELIRLER HS } \\
\text {-Uzun Dönemli Ertelenmiş Gelirin Kısa Dönemli Ertelenmiş Gelirler Hesabına } \\
\text { Virman Kayd1- }\end{array}$ & & $2.026,32$ \\
\hline
\end{tabular}

\begin{tabular}{|c|c|c|}
\hline 380 ERTELENMIŞ GELİRLER HS & \begin{tabular}{|l|} 
Borç \\
$2.026,32$
\end{tabular} & $\begin{array}{l}\text { Alacak } \\
2.026,32\end{array}$ \\
\hline -Faiz Gelirinin Gelirler Hesabına Alınması Kaydı- & & \\
\hline
\end{tabular}

VUK'a göre yapılması gereken kayıtta finansman unsurları dikkate alınmadan satış işlemine konu olan edilen tutar üzerinden gelir ölçülmeli ve dönem geliri olarak finansal tablolarda raporlanmalıdır.

\begin{tabular}{|c|c|c|}
\hline $\begin{array}{l}600 \text { YURT İÇİ SATIŞLAR HS } \\
391 \text { HESAPLANAN KDV HS }\end{array}$ & $\begin{array}{l}\text { Borç } \\
1.274 .400,00\end{array}$ & $\begin{array}{l}\text { Alacak } \\
1.080 .000,00 \\
194.400,00\end{array}$ \\
\hline -Vadeli Satış İşlemi Gerçekleşen Stokların Satış Kaydı- & & \\
\hline
\end{tabular}


Stoğun satış işlemi ile birlikte 11.01.2020 tarihinde hesaplanan tutar "621 Satılan Ticari Malların Maliyeti" hesabının borcuna "153 Ticari Mallar" hesabının alacağına kaydedilmelidir.

\begin{tabular}{|c|l|l|}
$\begin{array}{c}\text { B21 SATILAN TICARİ MALLLARIN MALIYETI HS } \\
\text { 153 TICARI MALLAR HS }\end{array}$ & Alacak \\
- Satılan Malın Maliyeti Kayd1- & $350.000,00$ & \\
\end{tabular}

Yapılan bu muhasebe kayıtlarına göre ABC A.Ş. işletmesine ait gelir tablosu aşağıdaki gibi oluşacaktır.

Tablo 1. ABC A.Ş.'nin Gelir Tablosu

\begin{tabular}{|l|l|l|l|}
\hline & BOBİ FRS & TMS 2 Stoklar & VUK \\
\hline Satış Hasılatı & $960.000,00$ & $960.000,00$ & $1.080 .000,00$ \\
\hline Satış Maliyeti & $350.000,00$ & $340.000,00$ & $350.000,00$ \\
\hline Brüt Satış Karı & $\mathbf{6 1 0 . 0 0 0 , 0 0}$ & $\mathbf{6 2 0 . 0 0 0 , 0 0}$ & $\mathbf{7 3 0 . 0 0 0 , 0 0}$ \\
\hline Faiz Geliri & $2.026,32$ & $2.026,32$ & 0,00 \\
\hline Faiz Gideri & 0,00 & 910,18 & 0,00 \\
\hline Dönem Kari/Zararı & $\mathbf{6 1 2 . 0 2 6 , 3 2}$ & $\mathbf{6 2 2 . 9 3 6 , 5 0}$ & $\mathbf{7 3 0 . 0 0 0 , 0 0}$ \\
\hline
\end{tabular}

ABC A.Ş.'nin gelir tablosunun sonuç hesabı olan dönem karı/zararı tutarı BOBİ FRS, TMS 2 Stoklar ve VUK'a göre farklı tutarlarda oluşmuştur. Oluşan bu farklılıkların nedenini şu şekilde açıklayabiliriz;

- Stokların satış işlemi 540 gün vadeli olduğundan dolayı VUK'a göre vade farkı ayrılmadan 1.080.000,00 TL olarak hesaplanan satış hasılatı BOBİ FRS ve TMS'ye göre vade farkı ayrılıp 960.000,00 TL olarak gelir tablosuna yansitılmıştır.

- Stokların satış maliyeti BOBİ FRS'de vade süresinin 1 yılın altında olmasından ve VUK'a göre vade farkı ayrıştırma uygulaması yapılmadığından dolayı 350.000,00 TL olarak kayıtlara alınırken 10.000,00 TL olan vade fark1 TMS 2 Stoklar standardınca stok maliyetine eklenmemiş, stokların satış maliyeti 340.000,00 TL olarak kayıtlara alınmıştır.

- Satış hasılatlarından satış maliyetleri çıkarıldığı takdirde ABC A.Ş.'nin brüt satış karı BOBİ FRS'ye göre $610.000,00$ TL, TMS'ye göre 620.000,00 TL ve VUK'a göre 730.000,00 TL olarak bulunacaktır.

- Stok satış işleminin vade süresi 1 yılın üzerinde kararlaştırıldığından dolayı BOBİ FRS'ye göre döneme isabet eden faiz geliri EFY uygulanarak 2.026,32 TL olarak hesaplanmıştır. Aynı tutar TMS 2 Stoklar standardınca da geçerlidir. VUK uyarınca satış işlemi esnasında ortaya çıkan vade farklılıkları satış hasılatının içerisine dahil edilmiş ve faiz geliri hesaplanmamiştır.

- Faiz giderleri BOBI FRS'ye göre 0,00 TL olarak oluşmuş bunun nedeni ise stok satın alımında 1 yılın altında belirlenen vade sürelerinde vade farkı ayrıştırma işleminin yapılmadan doğrudan stok maliyetine dahil edilmesidir. VUK'a göre de faiz giderleri stok satın alımı esnasında herhangi bir vade farkı hesaplamasının yapılmamasından dolayı 0,00 TL olarak raporlanmıştır. TMS 2 Stoklar standardına göre ise stok satın alımı esnasında vade 
farkları ayrıştırılmış ve EFY'ye göre hesaplanan döneme isabet eden faiz gideri 910,18 TL olarak gelir tablosuna yazılmıştır.

- BOBİ FRS, TMS 2 Stoklar ve VUK stoklar ile ilgili maddeler arasındaki uygulama farklılıklarına göre ABC A.Ş.'nin gelir tablosu sonucunda yer alan dönem karı/zararı tutarı sırası ile 612.026,32 TL, 622.936,50 TL ve 730.000,00 TL olarak tespit edilmiştir.

Yapılan uygulama sonucunda finansman unsurlarının BOBİ FRS, TMS 2 Stoklar ve VUK uygulamalarına göre işletmelerin gelir tablolarında farklı sonuçlara yol açtığı tespit edilmiştir. Stoklar ile ilgili işlemlerde vade sürelerinin 1 yılın altında veya üstünde belirlenmesi işletmelerin gelir tabloları sonucuna doğrudan etki etmektedir. Stok satın alımında vade farkının ayrıştırıldığı durumlarda satış maliyeti düşmekte, sadece döneme isabet eden vade farkı gelir tablosunda raporlanmaktadır. Stok satın alımı esnasında vade farkı hesaplanmadığı durumlarda satışların maliyeti yüksek çıacak, faiz gideri oluşmayacaktır. Stok satış işlemlerinde vade farkı ayrıştırılırsa satış hasılatı düşük çıkmakta faiz geliri oluşmakta, vade farkı ayrıştırılmaz ise satış hasılatı ve sonucunda brüt satış karı sonucu yüksek tutardan oluşmaktadır.

\section{SONUÇ VE ÖNERILER}

Stoklar hesap grubu, işletmelerin en çok işlem gören ve dönem sonu kar/zarar tablosuna en fazla etkide bulunan hesap gruplarından birisi olmakla birlikte birçok hesap kalem ile etkileşimde olduğu için işletmelerin en fazla dikkat etmesi gereken hesap gruplarının başında gelmektedir. TMS ve VUK'a ek olarak 01.01.2018 tarihi itibariyle BOBİ FRS mevzuatımıza dahil olmuş uygulayıcılar ile birlikte finansal tablo kullanıcıları açısından da karmaşık bir durum ortaya çıkmıştır. Bu karmaşıklığı ortadan kaldırmak ve BOBİ FRS'nin diğer standartlar arasındaki farklılık ve benzerlikleri ortaya koymak amacı ile oluşturulan çalışma sonucunda BOBİ FRS'nin TMS 2 Stoklar ve VUK stoklar maddeleri ile büyük ölçüde benzerliklere sahip olduğu, bu iki standart ile ilgili maddelerin ortasında konumlandırıldığı görülmüştür. BOBİ FRS'nin diğer standartlara göre büyük ölçüde benzer olduğu sonucuna ulaşılsa da kar/zarar tablosu sonucuna etki edecek farklılıkların olduğu da tespit edilmiştir.

İçerik analizi yöntemi ile yapılan inceleme sonucunda; ilk satın alma, maliyet ölçüm teknik ve hesaplama yöntemleri ile birlikte stokların gider olarak kayıtlara alınması işlemlerinin benzer olduğu, finansman unsurları, maliyet hesaplama yöntemleri ve hizmet sunan işletmelerdeki stok satışının gelir olarak yansıtılması işlemlerinde ise farklılıkların bulunduğu sonucuna ulaşılmıştır.

BOBİ FRS ve TMS 2 Stoklar standartlarında hizmet işletmelerinin üretmiş olduğu hizmetler ile ilgili maliyetler, maliyete katlanılan dönemde değil hizmet satışının gerçekleştiği dönemde hasılat ile birlikte eş zamanlı olarak kayıtlara alınır ve gelir tablosunda raporlanır. VUK'da ise bu durum satış işleminin gerçekleştiği zamana bağlı olmayıp maliyetlerin meydana geldiği dönemde gelir tablosuna yansitılmalıdır.

Stok maliyet hesaplama yöntemleri için BOBİ FRS'de tam maliyet yöntemi veya normal maliyet yöntemlerinden işletmeye uygun olanın uygulanacağı, TMS 2 Stoklar standardına göre normal maliyet yönteminin uygulanması gerektiği ve VUK'a göre ise tam maliyet yönteminin dikkate alınması hüküm altına alınmıştır. Maliyet hesaplama yöntemlerindeki bu farklılık stok birim maliyetlerinin farklı tutarlarda oluşması ile birlikte gelir tablosunda 
yer alan Satılan Malın Maliyeti kalemini etkileyecek ve işletmenin dönem karı/zararı tutarına doğrudan etkide bulunacaktır.

Çalışmanın uygulama bölümünde gelir tablosuna etkisi gösterilen finansman unsurlarının uygulamaları standartlara göre farklılık arz etmektedir. BOBI FRS' de vadeli alımlarda ortaya çıkan finansman giderleri 1 yıl sınırı ile uygulanmakta, 1 yılın altında olan vadelerde meydana gelen tutar farklılıkları dönem gideri olarak kayıtlara alınmakta 1 yılın üzerindeki vadelerde ise stok maliyetine dahil edilmektedir. TMS 2 Stoklar standardında herhangi bir süre sınırlaması olmadan tüm tutar farklılıkları stok maliyetine dahil edilmeden dönem gideri olarak kayıtlara alınmalıdır. VUK'a göre ise vade farklılıklarında herhangi bir tutar ayrıştırılması yapılmadan satın alınan tutar ile stoklar işletme envanterine dahil edilir. Çalışmanın uygulama bölümünde de gösterildiği gibi finansman unsurları arasındaki standart farklılıkları dönem kar/zarar sonucunun farklı tutarlarda çıkmasına neden olmaktadir.

BOBİ FRS, VUK'un vergi bazlı olan raporlamasını TMS'nin uluslararası alana uygun raporlamasına yakınlaştırmakta ve TMS'lere geçiş yapacak firmalar için bir basamak niteliğinde gözükmektedir. TMS'leri ise VUK hükümlerine yakınlaştırarak uluslararası raporlamalara uygun raporlama yapmak isteyen ancak yeterli imkâna sahip olmayan işletmelere kolaylık sağlamaktadır. BOBİ FRS muhasebe ve vergi uygulamalarımızı uluslararası standartlara taşımakta önemli bir yapıtaşı olmuştur. Yerel mevzuatlarımızın uluslararası mevzuata uygun hale gelmesi sonucunda işletmelerimizin küresel boyutta rekabet gücü artacak bunun sonucunda da şüphesiz ülke ekonomimize pozitif yönde önemli katkısı olacaktır. Bu sebeple şirketlerimizin önce BOBİ FRS'ye daha sonrasında ise TMS'ye geçiş süreçlerini hızlandırmaya yönelik çalışmaların hız kesmeden devam ettirilmesi, yerel mevzuatlarımızın uluslararası standartlara göre güncellenmesi gerekmektedir.

\section{KAYNAKÇA}

Akyol, M. (2019). "Stok Değerlemesinde Maliyet Bedelinin Tespit Yöntemi ve Bir Özelge", Vergi Dünyası Dergisi, (449), 57-61.

Altıntaş, T. (2011). "Uluslararası Muhasebe ve Türkiye'de Muhasebe Hukuku”, Sosyal Bilimler Dergisi, (1), 162-174.

Aslan, T., Baral, G. \& Erdinç, Ç. (2016). “Geschıchte Der Rechnungslegung Und Haben Einen Einfluss Auf Wirtschaftlichen Beitrag", The Journal of International Management Research, (2), 150-164.

Avc1, A. ve Avc1, Ö. (2016). “Vade Farkı, Kur Farkı Ve Kredi Faizlerinin Türkiye Muhasebe Standartları ve Vergi Usul Kanunu Kapsamında Değerlendirilmesi", Mali Çözüm Dergisi, (134), 75-90.

Büyükmirza, K. (2012). Maliyet ve Yönetim Muhasebesi Tekdüzen'e Uygun Bir Sistem Yaklaşımı, Ankara: Gazi Kitabevi.

Demir, Ş. (2019). Türkiye Muhasebe ve Finansal Raporlama Standartları, Ankara: Seçkin Yayınları.

Demir, V. ve Bahadır, O. (2014). “Yeni Avrupa Birliği Yönergesi (2013/34 EU) Kapsaminda Bireysel ve Finansal Tablolar", Mali Çözüm Dergisi, (121), 13-33. 
Elagöz, İ. ve Özcan, S. (2020). “Borçlanma Maliyetlerinin MSUGT, TMS/TFRS ve BOBİ FRS Açısından Muhasebeleştirilmesi", Muhasebe ve Finansman Dergisi, (85), 77-90.

Ergin, N. (2016). “Vergi Mevzuatı ile TMS/TFRS'nin Değerleme Ölçüleri Açısından Karşılaştırılması", Vergi Dünyası Dergisi, (418), 9-20.

Fidan, M. M. (2019). “Stok Değer Düşüklügü: Vergi Usul Kanunu - Türkiye Finansal Raporlama Standartları ve Büyük ve Orta Boy İşletmeler Finansal Raporlama Standardı Karşılaştırılması", Vergi Dünyası Dergisi, (456), 53-66.

Gökçen, G., Öztürk, E., ve Güleç, Ö. (2018). “BOBİ FRS ve TFRS’nin Finansal Raporlara Etkileri Açısından Karşılaştırılması”, Finans Ekonomi ve Sosyal Araştırmalar Dergisi, (3), 437-457.

Gönen, S. ve Demir, Ç. (2012). “Vergi Usul Kanunu ve KOBİ TFRS Bölüm 13 Açısından Stokların Karşılaştırılması", Uluslararası Alanya İşletme Fakültesi Dergisi, 4(2), 163-171.

İnan, M. (2010). “Türkiye'de Kazanç Vergisinden Gelir ve Kurumlar Vergisine Geçiş Süreci: 1946-1960 Dönemi", Maliye Dergisi, (158), 349-364.

Kabataş, Y. ve Pamukçu, A. (2010). “TMS-2 Stoklar Standardı Kapsamında Hizmet Üretim Maliyetlerinin Muhasebeleştirilmesi", Muhasebe ve Finansman Dergisi, (48), 191-199.

Kara, S. (2019). Stokların BOBİ FRS ve Vergi Mevzuatı Açısından Değerlendirilmesi ve Bir Uygulama. T.C. Marmara Üniversitesi Sosyal Bilimler Enstitüsü Yayımlanmamış Yüksek Lisans Tezi.

Karacan, S., Çiftçioğlu, S., ve Kutlu, T. (2018). “TMS - BOBİ FRS - VUK Kapsamında Kur Farklarının Değerlendirilmesinin Karşılaştırılması", Uluslararası Turizm, İşletme, Ekonomi Dergisi, 2(1), 1-10.

Karapınar, A. ve Eflatun, A. (2019). 2019 BOBİ FRS - Büyük ve Orta Büyüklükteki Isşletmeler İ̧̧in Finansal Raporlama Standardı Uygulama ve Yorumları, Ankara: Gazi Kitabevi.

Kaya, Ayça. (2015). “Türkiye Muhasebe-Finansal Raporlama Standartları'na Göre Finansal Araçların Muhasebeleştirilmesi", Fırat Üniversitesi Sosyal Bilimler Dergisi, 25(1), 105121

Kaya, H. (2018). "Stoklara İlişkin TMS 2 ve BOBİ FRS Karşılaştırması", Muhasebe Bilim Dünyası Dergisi, 2(20), 262-285.

KGK (2014, Ağustos 21). "Kamu Gözetimi, Muhasebe ve Denetim Standartları Kurul Kararı”, https://www.resmigazete.gov.tr/eskiler/2014/08/20140826-5.htm, Erişim: 02.10.2020.

KGK (2017, Temmuz 29). “Kamu Gözetimi, Muhasebe ve Denetim Standartları Kurumundan: Büyük Ve Orta Boy İşletmeler İçin Finansal Raporlama Standardı Hakkında Tebliğ"', https://www.resmigazete.gov.tr/eskiler/2017/07/20170729M1.pdf, Erişim: 29.08.2020.

Kocamış, T. ve Yıldırım, G. (2019). BOBİ FRS Uyumlu Dönem Sonu Muhasebe Uygulamaları, İstanbul: Maliye Hesap Uzmanları Derneği Yayınları. 
Marşap, B., ve Barış̧̧ı, A. (2014). “TMS-2 Stoklar Standardına Göre Dönüştürme Maliyetlerinin Ürün Maliyetlerine Etkisi", Muhasebe ve Vergi Uygulamaları Dergisi, (1), $1-16$.

Örten, R., Kaval, H., ve Karapınar, A. (2008). Türkiye Muhasebe Finansal Raporlama Standartları (TMS-TFRS) Uygulama ve Yorumlar, Ankara: Gazi Kitabevi.

Özbirecikli, M. ve Kıymetli Şen, İ. (2018). “BOBİ FRS'nin Muhasebe Uygulamalarına Getirdiği Değişiklikler: BOBİ FRS, TMS/TFRS ve Mevcut Muhasebe Çerçevesi İçinde Bir İnceleme", Muhasebe ve Vergi Uygulamaları Dergisi, (Özel Sayı), 462-484.

Özerhan, Y. ve Sultanoğlu, B. (2018). Uygulamalı BOBİ Finansal Raporlama Standardı, Ankara: Gazi Kitabevi.

Özerhan, Y. ve Yanık, S. (2015). Açıklamalı ve Örnek Uygulamalı TMS-TFRS, Ankara: TÜRMOB Yayınları.

Sağlar, J. \& Ever, D. (2019). “Büyük ve Orta Büyüklükteki İşletmeler İçin Getirilen Finansal Raporlama Standartlarının Etkileri", Osmaniye Korkut Ata Üniversitesi İktisadi ve İdari Bilimler Fakültesi Dergisi, 3(2), 299-310.

Sayın, K. (2001). “İşletme Malzemeleri Ve Muhasebeleştirilmesi”, Mali Çözüm Dergisi, (54), $35-46$.

Selvi, Y. ve Ercan, M. (2018). “BOBİ FRS Kapsamında 'Stoklar'”, Muhasebe Enstitüsü Dergisi, 16(59), 47-57.

Sönmez, F. (2007). “TMS 2- Stoklar Hüküm ve Açıklamaları (Eski Tebliğlerle 25 No'lu SPK ve 13 No'lu TMS ile Karşılaştırmalı Olarak Sunumu)", Muhasebe ve Finansman Dergisi, (35), 150-160.

Taşpınar, İ. (2010). “Vergi Usul Kanunu Açısından Stokların Değerlemesi”, Vergi Raporu Dergisi, (135), 61-69.

T.C. Hazine ve Maliye Bakanlığ ${ }_{1}$ Gelir İdaresi Başkanlığ1. (1995, Mart 2). “238 Sıra Nolu Vergi Usul Kanunu Genel Tebliği”, https://www.gib.gov.tr/node/88514, Erişim: 27.09.2020.

T.C. Hazine ve Maliye Bakanlığı Gelir İdaresi Başkanlığı. (1987, Mart 24). "176 Sıra Nolu Vergi Usul Kanunu Genel Tebliği”, https://www.gib.gov.tr/node/87336, Erişim: 18.10.2020.

T.C. Hazine ve Maliye Bakanlığı Gelir İdaresi Başkanlığı. (2017, Ekim 19). “Maliyet Hesaplama Yönteminde Değişiklik Yapılması Hakkında Özelge", https://www.gib.gov.tr/maliyet-hesaplama-yonteminde-degisiklik-yapilmasi-hk, Erişim: 08.10.2020.

T.C. Hazine ve Maliye Bakanlığı Gelir İdaresi Başkanlığ1. (1961, Ocak 10). “Vergi Usul Kanunu", https://www.mevzuat.gov.tr/MevzuatMetin/1.4.213.pdf, Erişim: 10.09.2020.

Toroslu, V. (2010). Türkiye Muhasebe Standartlarında Stok-Maliyet İlişkisi: TMS 2 Stoklar TMS 23 Borçlanma Maliyetleri. T.C. Okan Üniversitesi Sosyal Bilimler Enstitüsü Yayımlanmamış Yüksek Lisans Tezi. 
KGK (2018, Aralık 13). “Kamu Gözetimi Muhasebe ve Denetim Standartları Kurumu Finansal Raporlama Standartlarına Uygun Hesap Planı Taslağı", https://www.kgk.gov.tr/Portalv2Uploads/files/Duyurular/v2/TFRS/EK2_Finansal\%20 Raporlama\%20Standartlar\%C4\%B1na\%20Uygun\%20Hesap\%20Plan\%C4\%B1\%20Tasl a\%C4\%9F\%C4\%B1.pdf, Erişim: 27.05.2020.

Yalçın, S. (2019). “Türkiye Finansal Raporlama Standartları, Büyük ve Orta Boy İşletmeler İçin Finansal Raporlama Standardı Ve Muhasebe Sistemi Uygulama Genel Tebliğlerinde Stoklar: Muhasebeleştirme, Değerleme, Sunum ve Açıklamalar", Dumlupınar Üniversitesi Sosyal Bilimler Dergisi, (60), 202-222.

Yalkın, Y., Demir, V. ve Demir, D. (2006). “Uluslararası Finansal Raporlama Standartları ve Türkiye'de Finansal Raporlama Standartlarının Gelişimi”, Mali Çözüm Dergisi,(76), 291-307. 